\title{
Mixed silage of Elodea and wheat straw as a substrate for energy production in anaerobic digestion plants
}

Daniela Gallegos ${ }^{1,3}$, Harald Wedwitschka' ${ }^{1}$, Lucie Moeller², Sören Weinrich', Andreas Zehnsdorf ${ }^{2 *}$, Michael Nelles ${ }^{3}$ and Walter Stinner ${ }^{1}$

\begin{abstract}
Background: Waterweeds (Elodea nuttallii and Elodea canadensis) are invasive neophytes, which have been proliferating at a phenomenal rate during the last decades in German waterways. In case of overgrowth, the strong covering of vegetation can cause problems in hydroelectric power plants and leads to limitations in ship and boat traffic as well as in use for bathing and fishing activities. After vegetation period, dead plants can accumulate and then negatively influence flood protection and water engineering works. For this reason, the aquatic biomass has been periodically removed and disposed without further use. In order to enable the energetic use of this water-containing substrate, the aim of the present study was the optimization of storage methods for an aquatic plant-based feedstock for biogas production. In climatic cold regions, substrate conservation is necessary in order to guarantee a year-round substrate availability. With waterweed (Elodea) taken as an example, the ensiling of aquatic plants was studied. The main focus was to develop practical methods for biomass conservation while producing high biogas yields.
\end{abstract}

Methods: Elodea was harvested in the river Parthe in Leipzig-Schönefeld in October 2015. Silage mixtures of Elodea and wheat straw were tested after 180 days of storage for $\mathrm{pH}$, volatile fermentation products, and methane potentials. The effect of different silage moisture contents and straw particle sizes on the substrate quality was studied.

Results: Results show that waterweeds can be stored by ensiling and can achieve considerable biogas yields. However, with a water content of about $95 \%$, the storability of the material is challenging. Mixed silage of waterweeds and wheat straw were suitable for storage in clamp silos. The $\mathrm{pH}$ values were between 4.9 and 6.5 , and the volatile fatty acid content as lactic acid ranged from 0.0 to $1.9 \%$ total solid. The mixed silages achieved methane potentials between 166 and $228 \mathrm{~mL} \mathrm{~g}^{-1}$ volatile solid (VS), which is equivalent to 52 and $72 \%$ of maize silage. Considering a methane potential of $228 \mathrm{~mL} \mathrm{~g}^{-1} \mathrm{VS}$ and costs for material pretreatment, the most promising silage variant was mixed silage from waterweeds and ground straw with $30 \%$ total solid content.

Conclusions: Long storability of waterweeds could be possible by ensiling fermentation. Mixed silages from Elodea and wheat straw show suitable substrate characteristics for biogas production and can achieve high biogas yields.

Keywords: Elodea genus, Waterweeds, Neophyte, Aquatic biomass, Aquatic macrophytes, Biogas production

\footnotetext{
* Correspondence: andreas.zehnsdorf@ufz.de

${ }^{2}$ Helmholtz Centre for Environmental Research-UFZ, Centre for

Environmental Biotechnology, Permoserstr. 15, 04318 Leipzig, Germany

Full list of author information is available at the end of the article
} 


\section{Background}

Aquatic plants play an important role in the biotope of flowing and standing waters as they are a habitat for small water animals including fries, as they excrete oxygen into the water and take up nutrients. Under good conditions, aquatic macrophytes can spread with phenomenal growth rates gaining large amounts of biomass in a short time. Strong covering of aquatic plant vegetation can lead to problems in the operational use of waterways and negatively influence flood protection and hydroelectric power generation. An overgrowth of aquatic macrophytes can prevent the use of lakes and rivers as recreation areas, in case leisure activities like bathing or fishing become severely impaired [1]. A special role is played by the invasive neophytes such as the Elodea genus, which has been proliferating during the last decades in German waterways. In several regions in Germany, Elodea needs to be removed from water bodies regularly every year. Most often, the aquatic macrophytes are mowed by use of mowing boats. The biomass obtained is thereby generally disposed without further use, and costs for water operators increase as a result [1]. Instead of an unused disposal of harvested aquatic macrophytes, they could be used as an alternative feedstock for biogas production.

Anaerobic digestion (AD) is a suitable organic waste handling technology based on the biochemical conversion of organic compounds into methane, which can be used for electrical energy and heat production. In comparison to conventional energy crops, water plants are not standing in a competition to animal feed or food. No additional agricultural areas for crop cultivation are necessary as water plants are a residue material produced during water management efforts. Several studies revealed the high biogas potential of aquatic macrophytes. Samples of $E$. nuttallii from five different lakes in Germany showed specific biogas yields of $415-520 \mathrm{~L}_{\text {biogas }} \mathrm{kg}^{-1}$ volatile solid (VS) [2], which is comparable to hay or cattle dung. However, for practical application, storage methods for aquatic plant-based feedstock need to be developed as in climatic cold regions, substrate conservation is necessary in order to guarantee a year-round substrate availability.

Storage prior to AD of these water plants can be possible by ensiling. Ensiling is a preservation method for wet biomass based on solid-state lactic acid fermentation under anaerobic conditions whereby lactic acid bacteria (LAB) convert water-soluble sugars into organic acids, mainly to lactic acid. The ensiling process involves four phases [3]. During the aerobic processes, the respiration of remaining oxygen occurs until it has been entirely consumed. When the ensiled mass has become anaerobic, the fermentation phase starts, forming lactic acid and organic acids, which accumulate and lower the $\mathrm{pH}$ of the silage to below 5.0. It usually lasts for several days or weeks. In well-processed silage, LAB dominate the fermentation, rapidly producing the low $\mathrm{pH}$ conditions that help to preserve the silage, and thus, the growth of detrimental microorganisms, mainly, enterobacteria, clostridia, yeasts, and molds, is inhibited, representing good-quality silage. During the storage period, the silage is sealed and no air penetrates. This may last several months or until the feed-out period as long as the $\mathrm{pH}$ is sufficiently low and anaerobiosis preserves. The fourth phase is the unloading phase for feeding, during which silos are opened and reexposed to air. This causes the growth of undesirable aerobic microorganisms initially present in the silage, such as yeasts and molds that may spoil the silage [4].

Energy crops are usually stored in clamp silos. The storage of waterweed is challenging because the material decays rapidly when it is removed from water and gets in contact with air. With a water content of about $95 \%$, the storage of this plant material in agricultural silos is impossible. An ensilaging with crops such as corn silage would reduce the silage quality of the more expensive commodities due to inadequate total solid content, enhanced buffer capacities, etc. For this reason, mixed silage of waterweeds and wheat straw was studied as a possible solution for ensilage.

The aim of this study was to develop a method for long time conservation of aquatic plant materials with suitability for storage in conventional clamp silos. Therefore, silage mixtures of water plants and wheat straw as an available agricultural residue material were tested for silage quality and biogas potential. The results of the study can be used to determine optimum conditions for substrate ensiling of aquatic biomass for biogas production.

\section{Methods}

\section{Raw materials}

Elodea biomass, which was a mixture of E. nuttallii and E. canadensis (see also Zehnsdorf et al. [5]), was harvested as whole plant in autumn 2015 from the experimental site, the Parthe river in Leipzig, Germany $\left(51^{\circ} 21^{\prime} 53.2^{\prime \prime} \mathrm{N}, 12^{\circ} 24^{\prime} 51.2^{\prime \prime} \mathrm{E}\right)$, and transported in plastic containers to the Deutsches Biomasseforschungszentrum (DBFZ, Leipzig, Germany). Processing and ensiling of Elodea were conducted directly after collection. Elodea biomass was manually washed with cold tap water to remove adherent soil and impurities. The whole Elodea plant was cut by hand to a particle size of approximately $3-5 \mathrm{~cm}$ and stored in sealed plastic barrels at $4{ }^{\circ} \mathrm{C}$ until further use.

Wheat straw (WS) was provided by the Department Thermochemical Conversion of the DBFZ. Straw samples were chopped to a particle size of $2.0 \mathrm{~cm}$ (Strohmühle, Hirlinger Landtechnik GmbH, Burladingen, Germany) and ground to a particle size of $0.2 \mathrm{~cm}$ (Bioextruder, 
Lehmann-UMT GmbH, Pöhl, Germany). Samples were stored under dry conditions at room temperature $\left(20^{\circ} \mathrm{C}\right)$ in sealed plastic barrels until its use.

The inoculum (average chemical characteristics: $\mathrm{pH} 7.62$, TS 1.62, VS $80.2 \%, \mathrm{NH}_{4}-\mathrm{N} 1.34 \mathrm{~g} / \mathrm{L}$, organic acids $53.01 \mathrm{mg} / \mathrm{L}$ ) used for biochemical methane potential (BMP) tests was acquired from the DBFZ research biogas plant, which uses maize silage and cattle manure as substrates. The digestate was sieved $(5 \mathrm{~mm})$, diluted with tap water, and degassed at $22{ }^{\circ} \mathrm{C}$ for 5 days to reduce specific biogas generation prior to inoculation in the BMP test.

\section{Silage preparation}

Ensiling of Elodea was carried out in a laboratory scale as described in Gallegos et al. [6]. Silages were prepared with Elodea and previously pretreated WS raw material. The moisture content of the mixed silages of Elodea and straw was adjusted to 30 and $45 \%$ total solid (TS), respectively. The following silages were generated: Elodea silage without straw (EN), Elodea silage containing chopped straw at a TS content of 30\% (ESC1), Elodea silage containing chopped straw at a TS content of $45 \%$ (ESC2), Elodea silage containing ground straw at a TS content of 30\% (ESG1), and Elodea silage containing ground straw at a TS content of $45 \%$ (ESG2).

Five hundred grams of each substrate was filled into vacuum sealer bags $(30 \times 50 \mathrm{~cm} \mathrm{PA} / \mathrm{PE}$, La.va, Germany). After filling, the bags were vacuum-packed (Cookmax Series 42, Pentagast eG, Künzel, Germany) to remove air between substrate particles and stored under anaerobic conditions in the dark at room temperature (approx. $20^{\circ} \mathrm{C}$ ) for a period of 180 days. A total number of 30 silages were prepared: six replicates for Elodea biomass and six replicates for each of four mixtures of Elodea and WS.

\section{Analytical methods and BMP tests}

Total solids (TS) and volatile solids (VS) were determined according to DIN EN 12880 [7] and DIN EN 12879 [8]. The TS content was analyzed by oven-drying the samples for $24 \mathrm{~h}$ at $105{ }^{\circ} \mathrm{C}$ (Binder, Germany), and the VS content was determined by burning the dried samples to ashes for $30 \mathrm{~min}$ at $220{ }^{\circ} \mathrm{C}$ and then for $2 \mathrm{~h}$ at $550{ }^{\circ} \mathrm{C}$ in a muffle furnace (Carbolite, UK). The TS and VS contents of all silages were corrected for volatile organic compounds that were lost during oven-drying including lactic acid, volatile short-chain fatty acids $\left(\mathrm{C}_{2}-\mathrm{C}_{7}\right)$, methanol, ethanol, and propanol according to Weißbach and Strubelt [9]. The method is based on empirical analyses of VS losses during oven-drying of corn silage as reference material. However, the method was applied as silage properties such as total TS, VS, and VFA concentrations of the tested Elodea straw and corn silage were similar and there are currently no VS correction methods developed for mixed silages of Elodea and straw.
Prior to chemical analyses, the fresh samples were ground to $\leq 1 \mathrm{~mm}$ and prepared as previously described by Dittrich-Zechendorf [10]. The approximate composition was carried out only for raw Elodea and WS biomass. The content of nitrogen was determined with the Kjeldahl method. Crude protein content was calculated as 6.25 multiplied by the elemental nitrogen content detected. Crude fat was determined gravimetrically after acidic hydrolysis with $3 \mathrm{M}$ hydrochloric acid followed up by extraction with hexane. Crude fiber was determined by boiling the samples in $\mathrm{H}_{2} \mathrm{SO}_{4}$ and $\mathrm{KOH}$ followed up by drying and ashing the samples at $500{ }^{\circ} \mathrm{C}$ for $2 \mathrm{~h}$. Acid detergent fiber (ADF), neutral detergent fiber (NDF), and acid detergent lignin (ADL) content were analyzed according to Weende and Van Soest methods using the FIBRETHERM ${ }^{\circ}$ system based on the FibreBag technology (C. Gerhardt, Germany). ADL was determined gravimetrically after adding $72 \%$ sulphuric acid to the bag from ADF analysis for $3 \mathrm{~h}$ at a temperature of $20-23{ }^{\circ} \mathrm{C}$ and drying for $24 \mathrm{~h}$ at $105{ }^{\circ} \mathrm{C}$ and finally ashing the sample in a muffle furnace at $500{ }^{\circ} \mathrm{C}$ for $2 \mathrm{~h}$. The methods are described in detail in Dittrich-Zechendorf [10].

For the analyses of volatile fatty acids (VFA), alcohols, and $\mathrm{pH}, 5 \mathrm{~g}$ of the ensiled samples were previously diluted with $100 \mathrm{~mL}$ of distilled water and homogenized by blending for $15 \mathrm{~min}$. The $\mathrm{pH}$ value was measured directly using a pH electrode Sen Tix 41 (WTW, Germany) in aqueous extracts. Lactic acid (LA), volatile fatty acids, and alcohols were analyzed in the ensiled samples as described by Apelt [11]. LA, VFA, including acetic acid, propionic acid, isobutyric acid, $n$-butyric acid, isovaleric acid, $n$-valeric acid, hexanoic acid, and benzaldehyde, and alcohols, including ethanol, 2-butanol, 1-propanol, 1-butanol, furfural, and 5-methylfurfural (5-HFM), were measured using the Headspace GC system, which consisted of a 7890 series II gas chromatograph (Hewlett Packard, USA) equipped with an HS40 automatic headspace sampler (Perkin Elmer, USA) and a flame ionization detector from Agilent FID Technologies.

BMP test at laboratory scale was conducted in accordance with VDI 4630 [12] using eudiometer devices (Neubert Glas GbR, Geschwenda, Germany) to determine the specific methane yields of the ensiled samples after 180 days. The methane potential of fresh Elodea plant material was determined using the automated methane potential test system 2 (Bioprocess Control, Lund, Sweden). The samples consisted of $450 \mathrm{~g}$ of inoculum and $2.5 \mathrm{~g}$ of VS of the substrate, each in three replications. The inoculum to substrate ratio (ISR) was approximately $2.5: 1$. The pure inoculum was measured to determine its methane yield and to subtract this from the other samples. The test was operated under mesophilic conditions $\left(38{ }^{\circ} \mathrm{C}\right)$. To monitor the inoculum performance, microcrystalline cellulose was used as a reference substrate. 
The BMP test was ended when the daily biogas production had reduced to $1 \%$ of the total biogas production over a period of five consecutive days. The gas composition was determined with a landfill gas monitor (GA2000, Ansyco, Karlsruhe, Germany). The specific methane yields were standardized to $273.15 \mathrm{~K}$ and $101.325 \mathrm{kPa}$.

\section{Kinetic modeling of the BMP tests}

Referring to the different model derivations presented by Brule et al. [13], an exponential two-pool model (model C) was used to evaluate the methane production kinetics of the discontinuous laboratory experiments. This model structure differentiates between a rapidly and slowly degradable fraction (two-pool) of the available substrate. Therefore, four model parameters need to be adjusted to depict the respective experimental results in detail: the total methane potential S ( $\mathrm{mL} \mathrm{g}^{-1} \mathrm{VS}$ ), the ratio of rapidly degradable substrate to total degradable substrate $\alpha(-)$, and the two first-order reaction constants for the degradation of rapidly degradable substrate $k_{\mathrm{F}}\left(\mathrm{d}^{-1}\right)$ and slowly degradable substrate $k_{\mathrm{L}}\left(\mathrm{d}^{-1}\right)$ components. Additionally, the coefficient of determination $R^{2}(-)$ was calculated to assess the kinetic modeling results of all individual samples.

The model implementation as well as the numeric parameter estimation is realized in the software environment Matlab as described by Brule et al. [13]. Furthermore, the implementation has been extended to include realistic constraints for all model parameters. Thus, the kinetic constants and biogas potential $(k$ and $S$ ) can only accept positive values, whereas the ratio between rapidly and slowly degradable substrate components $(\alpha)$ varies between 0 and 1 .

\section{Statistical analyses}

All data were analyzed with SAS v 10.0 software (SAS Institute INC., Cary, NC, USA), using a type I error rate $(\alpha)$ of 0.05 by analysis of variance, to determine if there were significant differences between treatments, and if differences existed, post hoc least significant difference (LSD) tests were used to determine where they occurred. The effects of different substrate, straw particle size, moisture content and particle size $\times$ straw biomass interaction on chemical parameters, silage fermentation products, and methane yields were conducted to test for linear relationship using fraction of variance explained by the regression line $\left(r^{2}\right)$ of the SAS statistical package.

\section{Results and discussion}

\section{Chemical characteristics of raw materials}

Chemical composition of freshly harvested Elodea and WS is presented in Table 1. Whole plant Elodea biomass showed a high water content, which is typical of aquatic plants [14]. The lignin, cellulose, and hemicellulose content of Elodea were found within the range reported for
Table 1 Chemical composition for raw materials

\begin{tabular}{llll}
\hline Parameter & WS & Elodea & Units \\
\hline Total solids (TS) & 86.5 & 6.76 & $\% \mathrm{FM}$ \\
Volatile solids (VS) & 95.1 & 59.75 & $\% \mathrm{TS}$ \\
Nitrogen (N) & 5.9 & 37.9 & $\mathrm{~g} \mathrm{~kg}^{-1} \mathrm{TS}$ \\
Ash & 67.7 & 402.5 & $\mathrm{~g} \mathrm{~kg}^{-1} \mathrm{TS}$ \\
Protein (N × 6.25) & 36.8 & 236.9 & $\mathrm{~g} \mathrm{~kg}^{-1} \mathrm{TS}$ \\
Crude fiber & 684.6 & 245.6 & $\mathrm{~g} \mathrm{~kg}^{-1} \mathrm{TS}$ \\
Crude fat & 10.1 & 3.2 & $\mathrm{~g} \mathrm{~kg}^{-1} \mathrm{TS}$ \\
Lignin & 121.3 & 21.56 & $\mathrm{~g} \mathrm{~kg}^{-1} \mathrm{TS}$ \\
Cellulose & 494.0 & 175.1 & $\mathrm{~g} \mathrm{~kg}^{-1} \mathrm{TS}$ \\
Hemicellulose & 283.0 & 46.6 & $\mathrm{~g} \mathrm{~kg}^{-1} \mathrm{TS}$ \\
C:N ratio & $95.4^{\mathrm{a}}$ & $10.0^{\mathrm{b}}$ & - \\
\hline
\end{tabular}

FM fresh matter

${ }^{\text {aD }}$ ata from M. Solé-Bundó et al. [22]

${ }^{\mathrm{b}}$ Data from Zehnsdorf et al. [5]

fast-growing species [15]. Furthermore, Elodea biomass was also characterized by a high ash and protein content compared to wheat straw $[5,16]$. WS was characterized by high TS and fiber contents as typically found for lingocellulosic biomasses $[17,18]$.

\section{Silage characteristics \\ Silage fermentation of elodea silages without and with the addition of WS}

The results of fermentation characteristics in Elodea silages without and with the addition of WS are presented in Table 2. The addition of WS, reduced particle

Table 2 Chemical characteristics, $\mathrm{pH}$, and products of silage fermentation of Elodea silages without and with addition of WS

\begin{tabular}{lllllll}
\hline Silage & $\begin{array}{l}\text { TS } \\
(\%)\end{array}$ & $\begin{array}{l}\text { VS } \\
(\% \mathrm{TS})\end{array}$ & $\begin{array}{l}\text { LA } \\
(\% \mathrm{TS})\end{array}$ & $\begin{array}{l}\mathrm{AA}^{1} \\
(\% \mathrm{TS})\end{array}$ & $\begin{array}{l}\mathrm{BA}^{2} \\
(\% \mathrm{TS})\end{array}$ & $\mathrm{pH}$ \\
\hline EN & $6.7 \pm 0.1$ & $63.5 \pm 1.0$ & $0.0^{\mathrm{b}}$ & $7.5^{\mathrm{a}}$ & $2.1^{\mathrm{a}}$ & $6.5^{\mathrm{a}}$ \\
ESC1 & $25.9 \pm 0.9$ & $90.0 \pm 0.5$ & $0.5^{\mathrm{a}} \mathrm{b}$ & $4.4^{\mathrm{b}}$ & $0.0^{\mathrm{b}}$ & $5.4^{\mathrm{c}}$ \\
ESC2 & $49.9 \pm 0.2$ & $90.7 \pm 0.4$ & $1.1^{\mathrm{a}, \mathrm{b}}$ & $1.5^{\mathrm{c}}$ & $0.0^{\mathrm{b}}$ & $5.8^{\mathrm{b}}$ \\
ESG1 & $25.7 \pm 0.3$ & $81.4 \pm 0.9$ & $0.0^{\mathrm{b}}$ & $3.0^{\mathrm{b}, \mathrm{c}}$ & $0.0^{\mathrm{b}}$ & $5.6^{\mathrm{b}}$ \\
ESG2 & $56.7 \pm 0.8$ & $92.0 \pm 0.6$ & $1.9^{\mathrm{a}}$ & $1.8^{\mathrm{c}}$ & $0.0^{\mathrm{b}}$ & $4.9^{\mathrm{d}}$ \\
S.E. $(n=3)$ & & & 1.04 & 2.54 & 1.16 & 0.55 \\
Pz & & & $*$ & n.s. & n.s. & $* *$ \\
Pz×Sb & & & $*$ & n.s. & n.s. & $* *$ \\
Moisture content & & $* * *$ & n.s. & n.s. & $* *$ \\
EN biomass & & & n.s. & $* * *$ & $* *$ & $* * *$ \\
WS & & $*$ & n.s. & n.s. & $* *$ \\
\hline
\end{tabular}

Different superscript letters in the same column indicate significant difference at $p<0.05$

$T S$ total solid, VS volatile solid, $L A$ lactic acid, $P z$ straw particle size effect, $P z \times$ $S b$ interaction particle size $\times$ substrate, EN E. nuttallii biomass effect, WS wheat straw biomass effect, n.s. not significant

${ }^{*} p<0.05,{ }^{* *} p<0.01,{ }^{* * *} p<0.001$

${ }^{1} A A$ acetic acid-sum of acetic acid and propionic acid

${ }^{2} B A$ butyric acid-sum of isobutyric, $n$-butyric, isovaleric, $n$-valeric, and $n$-caproic acid 
size and high TS content correlated positively with LA content $\left(r^{2}=0.58,0.58\right.$, and 0.61 , respectively), whereas EN biomass was positively correlated with butyric acid content $\left(r^{2}=0.74\right)$.

The LA content of all silages varied between 0.0 and $1.9 \%$ TS and increased by addition of WS $(p<0.05)$ and with decreasing the size of straw particles $(p<0.05)$ with significant interaction between these factors $(p<0.05)$. This difference was probably due to the fact that grinding is more effective at reducing the particle size than chopping. This reduction of particle size increases the available specific surface area. Therefore, hitherto inaccessible areas are exposed for enzymatic attack, converting polymers into monomeric sugars for a faster and easier LA fermentation [19]. Moisture content also had a significant effect on LA content $(p<0.001)$. Higher LA was measured in silages composed of straw at low moisture content, while no LA concentration was detected in Elodea silage. This might be explained by an increase in butyric acid during storage due to metabolic activity of clostridia. Since $1 \mathrm{M}$ of butyrate is produced from $2 \mathrm{M}$ of lactate, it is thus assumed that Elodea silage underwent butyric acid fermentation, consuming LA completely during the storage period. It was clearly observed that these differences between silages are mainly attributed to the water content of Elodea biomass as compared with straw biomass. This does not only affect the chemical composition of the silage, but also the activity of the microorganisms involved in the conservation process. These results agree with findings in herbage silages [20]. The authors described the lactic and butyric acid content as a function of TS content. In a range of about $28-50 \%$ TS, a continuing increase of LA occurs; however, above $50 \%$ TS content might depress lactic acid bacteria (LAB). The $\mathrm{pH}$ value was significantly affected by EN biomass $(p<0.001)$. Higher $\mathrm{pH}$ was determined in Elodea silage than in Elodea silages with straw. This might be due to higher butyric acid content in this silage which resulted in a rise in the $\mathrm{pH}$. In addition, this increase in $\mathrm{pH}$ might have also been caused by the relatively high buffering capacity of the raw Elodea biomass related to high ash contents. In comparison to straw, Elodea biomass has much higher water, protein, and ash contents (Table 1). The water dilutes VFA and osmotic active substances and the proteins as well as the cations from the ash, which buffers the silage acids. In silages containing straw, the heterofermentative $\mathrm{LAB}$ might have dominated the ensilage process. This can be explained by the different LAB, which are classified as homo- and heterofermentative LAB based on their by-products of sugar fermentation. Homofermenters convert hexoses almost exclusively into LA, while heterofermenters also convert hexoses homofermentatively into LA, but they are able to ferment pentoses into equimolar amounts of lactic and acetic acid via a phosphoketolase [21]. This may explain the high $\mathrm{pH}$ value in ESC1, ESC2, and ESG1 silages. With the $\mathrm{pK}_{\mathrm{a}}$ defined as the acid dissociation constant, measures the strength of an acid, the lower or more negative the number, the stronger and more dissociable the acid. The $\mathrm{pK}_{\mathrm{a}}$ of the analyzed organic acids ranked in the following order: $3.86>4.75>4.82$ (lactic, acetic, and butyric acid, respectively). Results also showed that the pattern of silage fermentation was greatly influenced by the chemical and microbiological characteristics of the ensiled materials present before ensiling. High moisture content suggests that proper preservation of Elodea biomass by ensiling is challenging. Ensiling of Elodea showed that its water content can reactivate undesirable microorganisms, resulting in high $\mathrm{pH}$ values. The $\mathrm{pH}$ value of Elodea silage observed in this study was not different from that reported by Zehnsdorf et al. [14], who studied the ensiling of $E$. nuttallii in combination with corn. The authors assumed that the Elodea genus is not suitable for direct ensiling, unless additional material with suitable total solids is added, which agrees with the results of the present study.

\section{Effects of ensiling on methane yield}

Table 3 shows the methane formation of Elodea and Elodea-straw mixture silages. The results indicated that the straw particle size significantly affects the methane yield $(p<0.001)$, whereas the different substrates used for the ensiling experiment showed no consistent trend.

Differences in methane yields were detected between ESG2 and ESC2 $(p<0.05)$. It was noted that the specific methane yield of the Elodea silages containing straw tended to increase for the silages composed of ground straw and to decrease for the silages composed of chopped straw; therefore, methane yield exhibited a strong correlation related to the grinding treatment $(p<0.01)$ applied to straw before ensiling. This may suggest that changes in methane yield after grinding the substrate prior to ensiling might be attributed to the digestibility of lignocellulosic biomass. An enhancing effect of grinding treatment on methane yields as compared with methane yields of chopped biomass is in accordance with the findings in literature for straw silages [6]. In addition, the authors characterized wheat straw as a comparatively cheap agricultural residue with a very low water content that can be used for improving material characteristics of very wet substrates prior ensiling. Generally, findings of enhanced methane production by mechanical treatment are in line with the outcome of previous studies [17]. The accumulative methane production shown in Fig. 1 implied that the highest methane yield was derived from fresh Elodea silage without straw and showed a $6 \%$ decreased methane yield. However, the ensiling of fresh Elodea leads to a 
Table 3 Methane production from Elodea and Elodea-straw mixture silages after 180 days of storage

\begin{tabular}{|c|c|}
\hline Silage & Specific methane yield ( $\left.\mathrm{mL} \mathrm{g}^{-1} \mathrm{VS}\right)$ \\
\hline EN without ensiling & $242.2 \pm 36.4^{\mathrm{a}}$ \\
\hline EN & $218.6 \pm 12.5^{\mathrm{a}}$ \\
\hline ESC1 & $205.7 \pm 12.5^{\mathrm{a}, \mathrm{b}}$ \\
\hline $\mathrm{ESC2}$ & $166.1 \pm 13.1^{b}$ \\
\hline ESG1 & $228.3 \pm 27.6^{a}$ \\
\hline ESG2 & $224.5 \pm 9.8^{\mathrm{a}}$ \\
\hline $\mathrm{Pz}$ & $* * *$ \\
\hline $\mathrm{Pz} \times \mathrm{Sb}$ & $* *$ \\
\hline EN biomass & n.s. \\
\hline WS & n.s. \\
\hline $\mathrm{SC} 1^{1}$ & $235.9 \pm 10.6$ \\
\hline $\mathrm{SC} 2^{2}$ & $214.2 \pm 7.7$ \\
\hline$S G 1^{3}$ & $275.4 \pm 10.3$ \\
\hline$S G 2^{4}$ & $243.8 \pm 6.0$ \\
\hline
\end{tabular}

Different superscript letters in the same column indicate significant difference at $p<0.05$

$P z$ straw particle size effect, $P z \times S b$ interaction particle size $\times$ substrate, $E N E$. nuttallii biomass effect, WS wheat straw biomass effect, n.s. not significant

${ }^{1}$ SC1 chopped straw at $30 \%$ TS

${ }^{2} \mathrm{SC} 2$ chopped straw at $45 \%$ TS

${ }^{3} \mathrm{SG} 1$ ground straw at $30 \%$ TS

${ }^{4} \mathrm{SG} 2$ ground straw at $45 \%$ TS

$1,2,3,{ }^{4}$ Data from Gallegos et al. [6]

${ }^{*} p<0.05,{ }^{* *} p<0.01,{ }^{* * *} p<0.001$

liquid silage material which was storable under laboratory conditions for 180 days without major energy losses. Elodea silage containing ground straw showed comparable methane yields, while Elodea silage containing chopped straw at $30 \%$ TS achieved a $10 \%$ decreased methane yield.

These results coincide with specific methane yields observed for E. nuttallii reported by Escobar et al. [2].
The authors reported that variability in methane yields among $E$. nuttallii biomasses from five different lakes is dependent on the site of biomass origin. Other authors described that these variations originate from differences in chemical composition due to different locations and growing conditions [14]. This aquatic plant provides nutrients and trace elements and can thus be beneficial for the substrate composition [5, 14]. Estimated kinetic parameters of the two-pool model are presented in Table 4. All model configurations can depict the experimental progression of the specific methane yield (Fig. 1) of individual silage compositions in great detail $\left(R^{2}>\right.$ 0.94). Furthermore, identical reaction kinetics for ESC2 $\left(k_{\mathrm{F}}=k_{\mathrm{L}} \approx 0.151 \mathrm{~d}^{-1}\right)$ and ESG1 $\left(k_{\mathrm{F}}=k_{\mathrm{L}} \approx 0.109 \mathrm{~d}^{-1}\right)$ reveal that the cumulative methane progression of the respective samples can also be approximated with equal accuracy by single first-order reaction kinetics (according to model A in Brule et al. [13]). The estimated total methane potential $\left(\mathrm{S}\right.$ or $\mathrm{S}^{*}$ ) mainly confirmed the positive effect of adding wheat straw to Elodea prior ensiling. Furthermore, the experimental data as well as the model revealed that silages containing high moisture content showed higher methane potential in comparison to silages containing low moisture content. This difference could be related to the fact that high moisture contents $(30 \%$ TS) and lower $\mathrm{pH}$ values coupled with prolonged storage durations during the ensiling process led to a solubilization and depolymerization of lignocellulosic material, which had a positive effect on methane formation. Based on fixed first-order reaction constants, the EN sample was able to accelerate the digestion process, since the ratio between rapidly and slowly degradable substrate components was highest with $\alpha^{*}=0.97$, while silages composed of straw showed much lower ratios. In general, the addition of pretreated straw either by chopping or grinding at different moisture contents was not able to

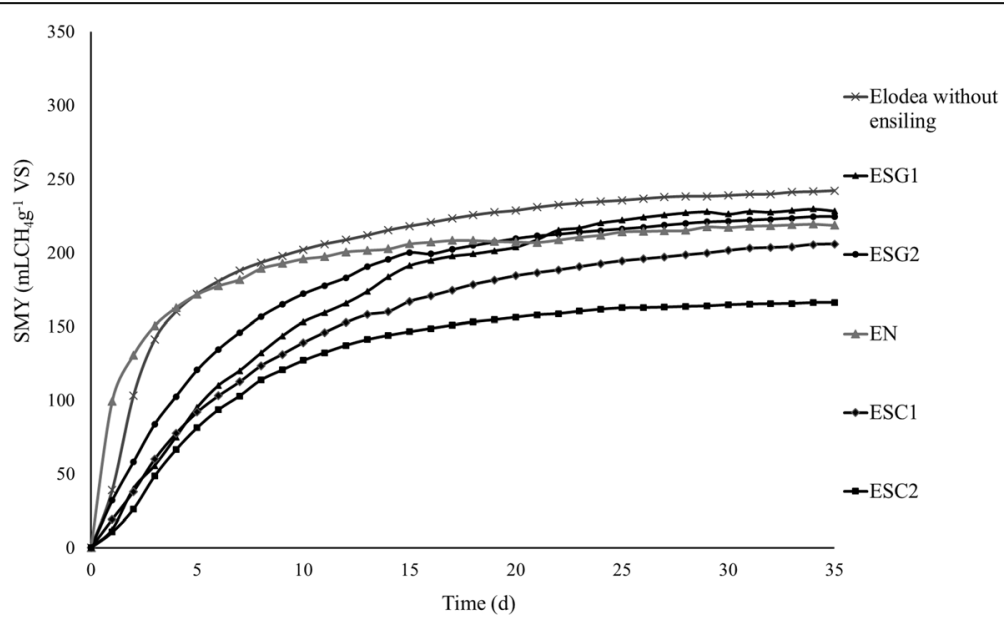

Fig. 1 Cumulative specific methane yield (SMY) of Elodea without ensiling; Elodea silage without straw (EN), Elodea silage containing chopped straw at 30\% TS (ESC1), Elodea silage containing chopped straw at 45\% TS (ESC2), Elodea silage containing ground straw at 30\% TS (ESG1), and Elodea silage containing ground straw at 45\% TS (ESG2) 
Table 4 Estimated model parameters of the utilized two-pool kinetic model (according to model C in Brule et al. [13])

\begin{tabular}{|c|c|c|c|c|c|c|c|c|c|}
\hline & $\begin{array}{l}\text { Data } \\
\left(\mathrm{mL} \mathrm{g}^{-1} \mathrm{VS}\right)\end{array}$ & $\begin{array}{l}\mathrm{S} \\
\left(\mathrm{mL} \mathrm{g}^{-1} \mathrm{VS}\right)\end{array}$ & $\begin{array}{l}a \\
(-)\end{array}$ & $\begin{array}{l}k_{F} \\
\left(d^{-1}\right)\end{array}$ & $\begin{array}{l}k_{\mathrm{L}} \\
\left(\mathrm{d}^{-1}\right)\end{array}$ & $\begin{array}{l}R^{2} \\
(-)\end{array}$ & $\begin{array}{l}\mathrm{S}^{\mathrm{a}} \\
\left(\mathrm{mL} \mathrm{g}^{-1} \mathrm{VS}\right)\end{array}$ & $\begin{array}{l}a^{a} \\
(-)\end{array}$ & $\begin{array}{l}R^{2 a} \\
(-) \\
\end{array}$ \\
\hline ESC1 & 206 & 260 & 0.70 & 0.1263 & 0.0120 & 1.00 & 220 & 0.19 & 1.00 \\
\hline ESC2 & 166 & 161 & 0.50 & 0.1508 & 0.1506 & 0.99 & 180 & 0.30 & 0.98 \\
\hline ESG1 & 228 & 231 & 0.46 & 0.1095 & 0.1094 & 1.00 & 252 & 0.12 & 0.99 \\
\hline ESG2 & 224 & 275 & 0.73 & 0.1707 & 0.0113 & 1.00 & 238 & 0.40 & 1.00 \\
\hline EN & 219 & 218 & 0.59 & 1.0899 & 0.1315 & 1.00 & 213 & 0.97 & 0.94 \\
\hline
\end{tabular}

${ }^{a}$ Optimized values (curve fitting) for fixed parameter values of $k_{\mathrm{F}}=0.3393\left(\mathrm{~d}^{-1}\right)$ and $k_{\mathrm{L}}=0.0780\left(\mathrm{~d}^{-1}\right)$, respectively. Fixed first-order reaction constants were calculated as the mean value of the individual kinetic parameters $\left(k_{\mathrm{F}}\right.$ and $k_{\mathrm{L}}$ ) over all experiments

Data final experimental value of the discontinuous digestion test (according to VDI 4630 [12]), $S$ estimated total methane potential (at infinite retention time), $a$ ratio of rapidly degradable substrate to total degradable substrate, $k_{F}$ first-order reaction constant for rapidly degradable substrate components, $k_{L}$ first-order reaction constant for slowly degradable substrate components, $R^{2}$ coefficient of determination

improve the degradation rate for rapidly degradable substrate components $\left(k_{F}\right)$, which might be attributed to the recalcitrance of lignocellulosic biomass to enzymatic hydrolysis, since wheat straw is a highly fibrous substrate [6].

The results of the study showed that laboratory scale produced silage from Elodea and straw showed suitable material characteristics for silage storage in conventional agricultural driving silos or also called bunker silos. The results indicate that straw pretreatment had an effect on the methane potential of the mixed silage. However, further economic assessments are necessary to estimate the economic feasibility of straw pretreatment, considering the high energy effort for straw grinding.

\section{Conclusions}

Long storability of waterweeds can be achieved by ensiling fermentation. Ensiling has the additional effect to enhance digestibility and biogas yields on lignocellulose substrates. To adapt the characteristics, a mixture of aquatic plants with straw prior ensiling is an adequate and practicable measure. Mixed silages from Elodea and wheat straw show suitable substrate characteristics for ensiling and biogas production and can achieve high biogas yields. Although the experiments have only been done at a laboratory scale, for practical applications, the mixture of waterweeds with straw to a TS of approx. $30 \%$ can be recommended.

On the experimental level with only small ensiling bags, the stability of the silages under practical conditions could not be investigated. The lower risk of air integration and the higher amount of acetic acid leads to the recommendation for TS of around 30\%, but as the silage with lower moisture showed lower $\mathrm{pH}$ probably due to reduced dilution, this should be investigated under practical conditions for future optimization.

Due to capacity restrictions, the experiments were only done with wheat straw. In principle, mixtures of waterweeds with different more dry lignocellulosic substrates are possible. Typical harvest times for aquatic weeds are in summer time for recreation water bodies and in autumn for rivers (protection of water constructions against aggradations). For this reason, different mass flow combinations (e.g. in autumn, a combination with maize straw) and efficient process chains need to be investigated.

\section{Additional file}

Additional file 1: Supplementary information and raw data. (PDF 520kb)

\section{Abbreviations}

AA: Acetic acid; AD: Anaerobic digestion; ADF: Acid detergent fiber; $\mathrm{ADL}$ : Acid detergent lignin content; BA: Butyric acid; BMP: Biochemical methane potential; C:N: Carbon-nitrogen ratio; EN: Elodea biomass;

ESC1: Elodea silage containing chopped straw at a TS content of 30\%; ESC2: Elodea silage containing chopped straw at a TS content of 45\%; ESG1: Elodea silage containing ground straw at a TS content of $30 \%$; ESG2: Elodea silage containing ground straw at a TS content of 45\%; FM: Fresh matter; $k_{F}$ : First-order reaction constant for the degradation of rapidly degradable substrate $\left[\mathrm{d}^{-1}\right] ; k_{\mathrm{L}}$ : First-order reaction constant for the degradation of slowly degradable substrate $\left[\mathrm{d}^{-1}\right]$; LA: Lactic acid; NDF: Neutral detergent fiber; $R^{2}$ : Coefficient of determination; S: Estimated total methane potential $\left[\mathrm{mL} \mathrm{g}^{-1} \mathrm{VS}\right] ; \mathrm{S}^{*}$ : Optimized total methane potential $\left[\mathrm{mL} \mathrm{g}^{-1} \mathrm{VS}\right]$; SMY: Specific methane yield $\left[\mathrm{mL} \mathrm{g}^{-1} \mathrm{VS}\right]$; TS: Total solids [\%FM or $\mathrm{g} \mathrm{gFM}^{-1}$ ]; VFA: Volatile fatty acids; VS: Volatile solids [\%TS or g gTS ${ }^{-1}$ ]; WS: Wheat straw; a: Ratio of rapidly degradable substrate to total degradable substrate

\section{Acknowledgements}

This project was funded by the German Federal Ministry of Food and Agriculture based on a decision of the German Bundestag with funds from the "Energy and Climate Fund" (grant number 22403013). The authors would like to thank Mrs. Bärbel Haase, Ms. Susann Hoffmann, Mr. Martin Apelt, Mr. Marcel Schneider, Mr. Markus Gießmann and Mr. Prem Kumar Rajendran for their assistance in conducting the experiments and Mrs. Tina Schmalfuß for carrying out the English correction. The authors also appreciate the financial support of the National Council for Science and Technology (CONACYT) of Mexico, through grant number 291077.

\section{Funding}

The investigations forming the basis for this article were carried out within the framework of the "Aquatic macrophytes-Optimal ecological and economic use" (AquaMak) research project. The "AquaMak" project is supported by the German Federal Ministry of Food, Agriculture and Consumer Protection with funds from the so-called Energy and Climate Funds (EKF) on the basis of a decision of the German Parliament (grant number: 22403013). The project partners are the Helmholtz Centre for Environmental Research-UFZ, the Nürtingen-Geislingen University-HFWU, and the Deutsches BiomasseForschungsZentrum gemeinnützige $\mathrm{GmbH}-\mathrm{DBFZ}$.

Availability of data and materials

The datasets supporting the conclusions of this article are given in Additional file 1. 


\section{Authors' contributions}

DG performed the study for the article, collected and sorted the publications and the information material, applied the dataset for the calculations, evaluated the statistical analyses, and prepared the manuscript. HW was responsible for the batch tests and ensiling experiments and collected and analyzed the samples. SW carried out the assessment of the biomethane potential test kinetics. AZ, LM, and MN contributed to the consultations and critical reading of the manuscript. WS had the idea for the study and supervised it. All authors edited and approved the final manuscript.

\section{Ethics approval and consent to participate}

Not applicable.

\section{Consent for publication}

Not applicable.

\section{Competing interests}

The authors declare that they have no competing interests.

\section{Publisher's Note}

Springer Nature remains neutral with regard to jurisdictional claims in published maps and institutional affiliations.

\section{Author details}

'Department of Biochemical Conversion, Deutsches

Biomasseforschungszentrum gemeinnützige $\mathrm{GmbH}$, Torgauer Straße 116, 04307 Leipzig, Germany. ${ }^{2}$ Helmholtz Centre for Environmental Research-UFZ, Centre for Environmental Biotechnology, Permoserstr. 15, 04318 Leipzig, Germany. ${ }^{3}$ Faculty of Agricultural and Environmental Sciences, Chair of Waste Management, University of Rostock, Justus-von-Liebig-Weg 6, 18059 Rostock, Germany.

Received: 25 October 2017 Accepted: 22 January 2018

Published online: 01 March 2018

\section{References}

1. Zehnsdorf A, Hussner A, Eismann F, Rönicke H, Melzer A (2015) Management options of invasive Elodea nuttallii and Elodea canadensis. Limnologica 51:110-117

2. Escobar MM, Voyevoda M, Fühner C, Zehnsdorf A (2011) Potential uses of Elodea nuttallii-harvested biomass. Energy Sustainability Soc 1:43

3. Weinberg ZG, Ashbell G (2003) Engineering aspects of ensiling. Biochem Eng 13:181-188

4. Dunière L, Sindou J, Chaucheyras-Durand F, Chevallier I, Thévenot-Sergentet D (2013) Silage processing and strategies to prevent persistence of undesirable microorganisms. Anim Feed Sci Technol 182:1-15

5. Zehnsdorf A, Moeller L, Stärk HJ, Auge H, Röhl M, Stinner W (2017) The study of the variability of biomass from plants of the Elodea genus from a river in Germany over a period of two hydrological years for investigating their suitability for biogas production. Energy Sustainability Soc 7:15

6. Gallegos D, Wedwitschka H, Moeller L, Zehnsdorf A, Stinner W (2017) Effect of particle size reduction and ensiling fermentation on biogas formation and silage quality of wheat straw. Bioresour Technol 245:216-224

7. DIN EN 12880 (2001) Characterization of sludges-determination of dry residue and water content. DIN Deutsches Institut für Normung e. V, Berlin

8. DIN EN 12879 (2001) Characterization of sludges—determination of the loss on ignition of dry mass. DIN Deutsches Institut für Normung e. $V$, Berlin

9. Weißbach F, Strubelt C (2008) Correcting the dry matter content of maize silages as a substrate for biogas production. Landtechnik Agric Eng 63(2): 82-83. https://doi.org/10.15150/lt.2008.779

10. Dittrich-Zechendorf M (2016) Determination of total Kjeldahl nitrogen and crude protein, determination of crude fat, determination of crude fibre, process specification for the determination of ADF and ADL and determination of neutral detergent fibre (NDF). In: Liebetrau J, Pfeiffer D, Thrän $\mathrm{D}$ (eds) Collection of methods for biogas. Series of the funding programme "biomass energy use" volume 7, ISSN online 2364-897X, pp 57-66

11. Apelt M (2016) Determination of organic acids. In: Liebetrau J, Pfeiffer D, Thrän $D$ (eds) Collection of methods for biogas. Series of the funding programme "biomass energy use" volume 7, ISSN online 2364-897X, pp 35-39
12. VDI 4630 (2014) Fermentation of organic materials — characterization of the substrate, sampling, collection of material data, fermentation tests, 2014-4th ed. Beuth Verlag, Berlin

13. Brulé $M$, Oechsner $H$, Jungbluth $T$ (2014) Exponential model describing methane production kinetics in batch anaerobic digestion: a tool for evaluation of biochemical methane potential assays. Bioprocess Biosyst Eng 37(9):1759-1770. https://doi.org/10.1007/s00449-014-1150-4

14. Zehnsdorf A, Korn U, Pröter J, Naumann D, Seirig M, Rönicke H, Pieper B (2011) Western waterweed (Elodea nuttallii) as a co-substrate for biogas plants. Agric Eng 66:136-139

15. Poorter H, Bergkotte M (1992) Chemical composition of 24 wild species differing in relative growth rate. Plant, Celt and Environment 15:221-229

16. Pörschmann J, Weiner B, Wedwitschka H, Zehnsdorf A, Köhler R, Kopinke FD (2015) Characterization of biochars and dissolved organic matter phases obtained upon hydrothermal carbonization of Elodea nuttallii. Bioresour Technol 189:145-153. https://doi.org/10.1016/j.biortech.2015.03.146

17. Schumacher B, Wedwitschka H, Hofmann J, Denysenko V, Lorenz H, Liebetrau J (2014) Disintegration in the biogas sector-technologies and effects. Bioresour Technol 168:2-6. https://doi.org/10.1016/j.biortech.2014.02.027

18. Romero-Güiza MS, Wahid R, Hernández V, Moeller H, Fernández B (2017) Improvement of wheat straw anaerobic digestion through alkali pretreatment: carbohydrates bioavailability evaluation and economic feasibility. Sci Total Environ 595:651-659. https://doi.org/10.1016/j.scitotenv.2017.04.006

19. Hendriks ATWM, Zeeman G (2009) Pretreatments to enhance the digestibility of lignocellulosic biomass. Bioresour Technol 100:10-18

20. Borreani G, Chion AR, Colombini S, Odoardi M, Paoletti R, Tabacco E (2009) Fermentative profiles of field pea (Pisum sativum), faba bean (Vicia faba) and white lupin (Lupinus albus) silages as affected by wilting and inoculation. Anim Feed Sci Technol 151:316-323

21. McDonald P, Henderson AR, Heron SJE (1991) The biochemistry of silage, second ed. Chalcombe Publications, Marlow, p 85

22. Solé-Bundó M, Eskicioglu C, Garfí M, Carrère H, Ferrer I (2017) Anaerobic codigestion of microalgal biomass and wheat straw with and without thermoalkaline pretreatment. Bioresour Technol 237:89-98

\section{Submit your manuscript to a SpringerOpen ${ }^{\circ}$ journal and benefit from:}

- Convenient online submission

- Rigorous peer review

- Open access: articles freely available online

- High visibility within the field

- Retaining the copyright to your article

Submit your next manuscript at $>$ springeropen.com 